\title{
Rocznik Nadwiślańskiego Urzecza Recenzja książki
}

22 marca 2019 r. w Ratuszu miasta i gminy Góra Kalwaria miała miejsce prezentacja Rocznika Nadwiślańskiego Urzecza, opracowana naukowo przez dra Łuksza Maurycego Stanaszka oraz dra Piotra Rytko. Publikacja została przygotowana przez Towarzystwo Opieki nad Zabytkami (Oddział w Czersku) i ma na celu dalszą popularyzację dziedzictwa historycznego i kulturowego Urzecza - regionu etnograficznego, położonego po obu stronach Wisły, na południe od Warszawy.

Treść pierwszego tomu Rocznika Nadwiślańskiego Urzecza jest mocno zróżnicowana i zawarta jest w dziewięciu tematycznych opracowaniach stanowiących - w moim odczuciu - przyczynek do poznania historii regionu.

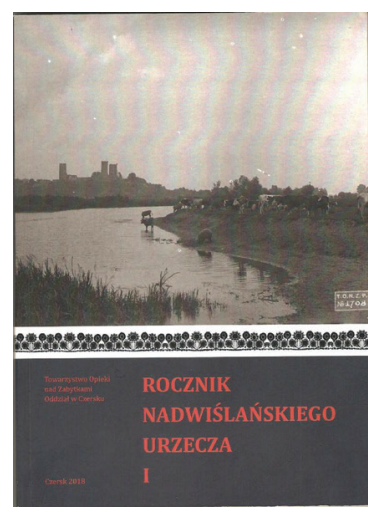

Paweł Komosa przedstawia Zarys historii systemów ochrony przeciwpowodziowej na nizinie Moczydłowskiej. W swoim opracowaniu Autor sięga do kataklizmu powodziowego z lat 1710 i 1715, niszczącego całkowicie wieś Kozłów i kościół w Cieciszewie. Przedstawia nam rolę i znaczenie pierwszej konstrukcji hydrotechnicznej - tamy usypanej ok. 1725 r. prostopadle do koryta Wisły, wskutek czego obroniła ona wieś Cieciszew przed falą powodziowa, kierując ją w starorzecze Wisły. Geografię terenu i koncepcję ochrony przeciwpowodziowej ilustrują dwie mapy oraz dwa zdjęcia.

Dużo miejsca poświęca Autor ewolucji prac zabezpieczających nizinę Moczydłowską oraz opisuje stosowaną technologię prac przy budowie wałów (np. s. 10 i 15). Interesująca jest struktura administracji odpowiedzialnej za ochronę przeciwpowodziowa, a w tym i rozbudowę wałów.

Lidia Sitek prezentuje opracowanie bibliograficzne Melchior Walbach - postać historycznego kupca związanego z Mazowszem i Warszawą XVI w. W interesującej formie podaje dzieje rodu kupca Walbacha, w tym jego potomków, a także zgromadzonego majątku. W drugiej części Autorka próbuje wyjaśnić skąd i jakim sposobem Melchior Walbach związał się w trwały sposób z Karczewem.

Renata Krasowska zaprezentowała opracowanie Fundacja Marszałka Franciszka Bielińskiego w Górze Kalwarii. Opracowanie składa się z kilku części połączonych osobą i życiem Franciszka Bielińskiego - marszałka koronnego. Charakteryzuje działalność Bielińskiego na rzecz Warszawy, jej rozwoju i unowocześnienia. Po wydarzeniach 1764 r. i w konsekwencji pozbawienia Go jurysdykcji marszałkowskiej wyjechał do swojej posiadłości w Otwocku. Był mocno związany ze współczesnym rejonem Czerska, Otwocka i Karczewa. 
W drugiej części Autorka prezentuje, w syntetyczny sposób, historię Góry Kalwarii sięgająca początku XV w., aby w kolejnej części ukazać historię kościoła pw. Niepokalanego Poczęcia NMP, wzniesionego w stylu barokowym w latach 1756-1759. Kościół został ufundowany przez Franciszka Bielińskiego, a wnętrza otrzymały wystrój barokowy i rokokowy. Fundacja marszałka Franciszka Bielińskiego dobrze wpisała się w historię Góry Kalwarii.

Opracowanie wzbogacone czterema - niestety - czarnobiałymi fotografiami w ciekawy sposób łączy historię, ludzi i budowle.

Lidia Sitek w opracowaniu Kościół św. Wita w Karczewie prezentuje historię, architekturę, miejsce i znaczenie kościoła w kształtowaniu społeczności Karczewa, a szerzej również Urzecza.

Historia kościoła św. Wita w Karczewie była już niejednokrotnie przedstawiana w różnych publikacjach. Jednak Lidia Sitek już w pierwszych zdaniach swojego tekstu rysuje tło historyczne okresu powstawania świątyni i podstawowe nurty architektoniczne konkurujące ze sobą w tym okresie. Podkreśla, „by jego architekturę rozpatrywać na tle architektury stolicy" (s. 46) oraz uzasadnia tę śmiałą tezę.

Bardzo interesujące opracowanie składa się z sześciu części: stan badań; historia miasta i kościoła; opis pierwotnego XVIII-wiecznego planu i bryły kościoła przed jego rozbudową; wystrój architektoniczny najstarszej, XVIII-wiecznej części kościoła; obecny wystrój wnętrza kościoła; architektura dobudowanej części kościoła oraz jej wystrój wewnętrzny; podsumowanie.

Zbigniew Węgrzynek przedstawia Osadnictwo na terenie nadwiślańskim w powiecie garwolińskim. Dawny powiat garwoliński, o większej powierzchni niż obecnie, był miejscem, na którym grupy osadnicze zakładały tzw. kolonie olęderskie (z Pomorza, Kujaw, Niemiec, Fryzji). Największy napływ osadników zanotowano pod koniec XVIII w., a początek migracji nad Wisłę dali Flamandowie i Walonowie.

Autor precyzyjnie opisuje historię i uwarunkowania osiedleń olenderskich.

Tomasz Gromadka prezentuje interesujaccy problem socjologiczno-genealogiczny dawnego Urzecza w postaci pytania Z rycerzy w chłopów? Genealogia Dąbrowskich herbu Lubicz i Olszanków z Urzecza. Jest to historia rodziny Dąbrowskich oraz spokrewnionej z nią rodziny Olszanków na tle prawie pięćsetletniej historii Mazowsza.

Historia obu rodów (a precyzyjnie ujmując Dąbrowskich) rozpoczyna się wzmianką z 1487 r. i jest doprowadzona do okresu międzywojennego. Logicznie przedstawiona, mocno udokumentowana i wsparta kilkoma faktami powiązanymi z wydarzeniami historycznymi stanowi ciekawy i pouczający materiał. Lektura tego opracowania prawdopodobnie zachęci inne rody z Urzecza do badań genealogicznych. Na podkreślenie zasługuje fakt, że opracowanie T. Gromadki współgra z opracowaniami np. Marii Zaręby z d. Paczesna i w pewnym sensie z tekstem Łukasza M. Stanaszka znajdujących się w tejże publikacji.

Łukasz Maurycy Stanaszek - w opracowaniu Pochodzenie porucznika Jerzego Gawina "Stonia" prezentuje losy jednego z bardziej współczesnych przedstawicieli rodu Gawinów, związanego z regionem Urzecza od XVI w. Prekursorem rodu był prawdopodobnie Andrzej Jeli- 
to pełniący od 1539 r. funkcję książęcego przewoźnika czerskiego. Jerzy Gawin (1922-1944) pseudonim „Słoń” był synem Marcelego Gawina i Janiny Koszelik. Był żołnierzem AK i zginął w czasie Powstania Warszawskiego na Mokotowie.

Barwnie poprowadzony opis historii rodziny ukazuje Jerzego Gawina jako człowieka powiązanego z Urzeczem i odważnego patrioty. Całość uzupełnia ciekawy i różnorodny materiał ilustracyjny (mapy, zdjęcia, wykresy).

Jan Gustaw Rokita podejmuje nietypowy temat - Tradycje kulinarno-gastronomiczne miasta i gminy Góra Kalwaria. Rys historyczny będący próbą spojrzenia na tradycje kulturalne regionu z nietypowej strony. Opracowanie przedstawia raczej uwarunkowania społeczno-historyczne kształtowania się tradycji kulinarno- gastronomicznych związanych z miejscem lokacji miasta i migracją ludności w XVIII i XIX w.

Jak wynika z treści opracowania ludność Góry Kalwarii (dawniej Nowej Jerozolimy) raczej nie wypracowała własnej tradycji kulinarnej, a potrawy są wypadkową żywieniowych upodobań licznych grup mieszkańców Urzecza. Jedynie na s. 136 Autor bardziej konkretnie odnosi się do tematyki opracowania - prezentuje wyliczankę kilkunastu tradycyjnych potraw, np.: zacierki na mleku, „sytocha”, barszcz chrzanowo-buraczany, kasza jaglana, powidła z buraków.

Nadmieniam, że niektóre z potraw Urzecza były poddawane degustacji przy okazji lokalnych imprez kulturalnych, np. Zielone Świątki na Urzeczu, Flis Festiwal, a barszcz z buraków był obecny na promocji omawianej publikacji.

Robert Lewandowski prezentuje materiał odnoszący się do szerszego problemu lokalnego nt. Linia Otwocka jako pasmo historyczno-urbanistyczne. Można przyjąć, że Linia otwocka to „firma" mająca istotny wpływ na ewolucję gospodarczą dość sporego obszaru na południe od Warszawy, obejmującego częściowo obszar kwalifikowany do dzisiejszego Urzecza. Historia tzw. linii otwockiej i wszystkiego, co się z tym kryje rozpoczęła się w 1847 r. - otwarciem Drogi Żelaznej Nadwiślańskiej.

Autor prowadzi plastyczną narrację rozwoju obszaru wokół Drogi Żelaznej ukazując przy tej okazji ewolucję architektoniczną osad, letnisk i miasteczek, a w tym znaczenie Michała Andriollego i jego stylu architektury - znanego powszechnie jako świdermajer.

Opracowanie bogato ilustrowane wycinkami stosownych map oraz stron tytułowych przewodników turystycznych.

Maria Zaręba z d. Paczesna w opracowaniu Przygoda z genealogia mieszkańców Czerska swoje opracowanie przedstawia na bazie osobistych doświadczeń z prowadzonych poszukiwań genealogicznych w sprawie korzeni własnej rodziny. Zainteresowania Autorki dotyczyły w pierwszej kolejności dwóch rodzin: Paczesnych oraz Szynkiewiczów, dwóch starych rodów czerskich. W przygotowanej tabeli ukazuje genezę spokrewnionych rodów od wspólnego przodka - Kacpra pojawiającego się w dokumentach w 1715 r. Treść udokumentowana jest skanami 6 dokumentów i 71 zdjęć.

To opracowanie jest przykładem budowania historii regionu poprzez jej przywiązanie do mieszkańców tworzących wspólnotę społeczności, dzisiaj nazywane „małymi ojczyznami”. 
Staranne wydanie edytorskie pierwszego Rocznika Nadwiślańskiego Urzecza budzi nadzieje na kontynuowanie, tym bardziej, że ten geograficzny obszar jest ciekawy pod każdym względem: historycznym, kulturowym, społecznym, gospodarczym.

\section{INFORMACJE O KSIĄŻCE}

Rocznik Nadwiślańskiego Urzecza, tom I, red. Ł. M. Stanaszek, P. Rytko. Wyd. Towarzystwo Opieki nad Zabytkami Oddział w Czersku, Czersk 2018. ISBN 978-83-939981-2-8.

Czesław Marcinkowski 